\title{
Systematic scoping review of factors and measures of rurality: toward the development of a rurality index for health care research in Japan
}

Makoto Kaneko ${ }^{1,2,3^{*}}$ (D), Ryuichi Ohta ${ }^{4}$, Evelyn Vingilis ${ }^{3}$, Maria Mathews ${ }^{3}$ and Thomas Robert Freeman ${ }^{3}$

\begin{abstract}
Background: Rural-urban health care disparities are an important topic in health services research. Hence, developing valid and reliable tools to measure rurality is needed to support high quality research. However, Japan, has no index to measure rurality for health care research. In this study, we conducted a systematic scoping review to identify the important factors and methodological approaches to consider in a rurality index to inform the development of a rurality index for Japan.

Methods: For our review, we searched six bibliographic databases (MEDLINE, PubMed, CINAHIL, ERIC, Web of Science and the Grey Literature Report) and official websites of national governments such as Government and Legislative Libraries Online Publications Portal (GALLOP), from 1 January 1989 to 31 December 2018. We extracted relevant variables used in the development of rurality indices, the formulas used to calculate indices, and any measures for reliability and validity of these indices.

Results: We identified 17 rurality indices from 7 countries. These indices were primarily developed to assess access to health care or to determine eligibility for incentives for health care providers. Frequently used factors in these indices included population size/density and travel distance/time to emergency care or referral centre. Many indices did not report reliability or validity measures.

Conclusions: While the concept of rurality and concerns about barriers to access to care for rural residents is shared by many countries, the operationalization of rurality is highly context-specific, with few universal measures or approaches to constructing a rurality index. The results will be helpful in the development of a rurality index in Japan and in other countries.
\end{abstract}

Keywords: Geography, Health services research, Japan, Rurality index, Scoping review

\footnotetext{
* Correspondence: kanekom@yokohama-cu.ac.jp

'Primary Care Research Unit, Graduate School of Health Data Science,

Yokohama City University, 22-2, Seto, Kanazawa-ku, Yokohama, Kanagawa 236-0027, Japan

${ }^{2}$ Department of Family and Community Medicine, Hamamatsu University

School of Medicine, 1-20-1, Handayama, Higashi-ku, Hamamatsu 431-3192,

Japan

Full list of author information is available at the end of the article
}

(c) The Author(s). 2021 Open Access This article is licensed under a Creative Commons Attribution 4.0 International License, which permits use, sharing, adaptation, distribution and reproduction in any medium or format, as long as you give appropriate credit to the original author(s) and the source, provide a link to the Creative Commons licence, and indicate if changes were made. The images or other third party material in this article are included in the article's Creative Commons licence, unless indicated otherwise in a credit line to the material. If material is not included in the article's Creative Commons licence and your intended use is not permitted by statutory regulation or exceeds the permitted use, you will need to obtain permission directly from the copyright holder. To view a copy of this licence, visit http://creativecommons.org/licenses/by/4.0/ The Creative Commons Public Domain Dedication waiver (http://creativecommons.org/publicdomain/zero/1.0/) applies to the data made available in this article, unless otherwise stated in a credit line to the data. 


\section{Background}

Addressing rural-urban health care disparities is an important health system challenge. Numerous studies have reported that rural residents are more likely to have chronic diseases related to obesity, and less likely to engage in healthy behaviours, compared to urban residents [1-4]. Rural residents have poorer access to health care providers and have fewer visits to family physicians and specialists than urban residents $[5,6]$. Moreover, living in a rural area is associated with lower physical/social functioning, mental health, self-reported health status [7], cancer survival [8], and overall quality of life [9]. Also, the recruitment and retention of the health care providers are major challenges in rural areas [10]. For example, Ontario, Canada originally developed the Rurality Index of Ontario (RIO) [11] in 2000 for policy purposes such as workforce incentives targeting physician recruitment and retention in rural areas [11]. Australia's Modified Monash Model (MMM) [12] was based on Humphreys's (2012) paper [13], and has been used to develop the recruitment and retention programs for health care providers [12]. However, a challenge for the development of rural indices is that many definitions of rurality exist as "rural" areas can include a wide range of community characteristics (e.g. level of affluence, degree of industrialization) [14, 15]. Yet most definitions of rurality focus on geographic characteristics (e.g., low population density or distance from health care resources) $[14,15]$, and not on social/cultural issues such as "way of life", and "state of mind" associated with rural living that can affect health disparities [15]. Additionally, different methods have been used to calculate these indices. For example, the RIO used a sum of community population, travel time to nearest referral centre and travel time to nearest advanced referral centre to produce a continuous variable from 0 to 100 [11] while the MMM used a combination of population size and geographical remoteness to provide a 7-level classification with 1 representing a major city and 7 representing a high level of remoteness [12].

In Japan, researchers and policy makers do not have a rurality index. Japan has 6800 islands and 683,000 (0.5\% of overall population) live on these islands [16]. Also, 11 million people live in rural areas called "depopulated areas" (11\% of overall and the area is $58 \%$ of all areas) and 130,000 people live in "districts without a doctor (the areas are defined as the area over 50 residents within a radius of $4 \mathrm{~km}$ with limited access) [16]. Although the national government classified the "depopulated areas" based on the municipality's income, demand and population trends, it is determined subjectively with no concrete definition or formula to consistently apply [17]. This existing index fails to capture the variation in health status and physician resources, ignores socio- cultural considerations, and is not widely accepted by primary care physicians [18].

In order to report comparisons between communities, researchers from various jurisdictions have developed indices to measure and categorize different degrees of rurality. Ensuring that a rurality index is valid and reliable is an integral step in promoting the widespread acceptance of the index, gathering high quality data, and developing strategies to tackle health and health workforce disparities [19].

The goal of this study is to identify the important factors and methods of measuring rurality for health services research and health policy. This scoping review is the first step in a project to develop a rurality index for Japan. The findings will also be useful for other countries and rural health researchers.

\section{Aims}

The aims of the scoping review are to 1) describe the publication characteristics of rurality indices, 2) identify factors commonly used in rurality indices, and 3) assess validity and reliability properties of published rurality indices.

\section{Methods \\ Study design}

A systematic scoping review.

A systematic scoping review is a review of existing literature to clarify a complex concept and refine subsequent research [20]. Usually, a systematic scoping review does not assess the quality of included studies, unlike a systematic review [20]. Also, a systematic scoping review is different from a narrative review because the scoping process requires analytical reinterpretation of the included literature [20]. A systematic scoping review is suitable for a discipline in which the shortage of randomized control trials makes it difficult for investigators to conduct a systematic review [20].

Arksey and O'Malley [21] presented a five-stage methodological framework to be used for scoping reviews that was further expanded by Levac et al. [20] The framework includes the following stages: identification of the research question; identification of relevant studies; selection of studies; charting of the data; collation, summarizing and reporting the results.

The systematic scoping review answers the research question: what are the factors, methods, and any measures for reliability and validity of rurality indices used in health care and health system related research.

\section{Search strategy (identifying relevant studies)}

We included articles and websites in English and Japanese. We searched the following bibliographic databases (MEDLINE, PubMed, CINAHIL, ERIC, Web of Science 
and the Grey Literature Report) to identify relevant papers. Also, we searched Government and Legislative Libraries Online Publications Portal (GALLOP), Registry of Canadian Government Information Digitization Projects, Canadian Research Index - Microlog, Municipal Information Network, Canadian Public Policy Collection, United Nations digital library, the US Census website and Organization for Economic Co-operation and Development (OECD) library to look identify rurality indices employed by national/local governments around the world. Moreover, we used Japanese databases, IchushiWeb, an online Japanese literature searching system provided by the non-profit Japan Medical Abstracts Society. Ichushi-Web includes roughly 10 million medical papers from 6000 journals in Japan and is often used for Japanese literature searches [22]. We included studies that were published from 1 January 1989 to 31 December 2018 (the last 30 years) and websites. The most recent search date was 10th September 2019. The search strategy was based on the following title/abstract keywords in English and Japanese: "rurality" OR "rurality index" OR "index of rurality" OR "rurality measurement" OR "remoteness index" OR "accessibility index" OR "population density index". Moreover, we added "develop" OR "create" OR "construct" OR "generate". In addition, we used MESH term: "Rural Health Services/classification" OR "peripherality index". We also reviewed the reference lists of relevant studies to identify research that might have been missed in the database search.

\section{Inclusion/exclusion criteria (study selection)}

Literature searches and study selection were independently conducted by two investigators ( $\mathrm{MK}$ and $\mathrm{RO}$ ) and any discrepancies were resolved by discussion.

We excluded articles and websites that used a previously developed rurality index.

\section{Data extraction (charting data)}

To report each study, we followed the approach of described in the PRISMA Extension for Scoping Reviews (PRISMA-ScR): Checklist and Explanation [23]. This checklist includes 22 essential reporting items that reflect on the title, abstract, introduction, methods, results, discussion and funding [23]. Based on an initial search of the literature, we developed an extraction template that included the following elements:

title of the article, name of authors, years of publication, name of the journal/website, name of the index, publication status (yes/no), peer review status (yes/no), citation index by Web of Science, country/province, unit of analysis (geographical jurisdiction/health care institution/individual), types of variable of rurality index (continuous/categorical), purpose of the index (for general purpose/for health care policy and research), study design, selection of factors included in the index, reported measures of reliability and validity.

We classified the unit of analysis into three categories: geographical jurisdiction, health care institution, or individual. The unit of analysis may vary depending on the purpose of the index. To assess rurality in specific areas, geographical jurisdiction is suitable for unit of analysis. Health care institution is employed for measurement of rurality from the viewpoint of each medical institution. Individual-level rurality is used for assessing each person's accessibility to health care.

We categorize the purpose of the index into two categories: for general purpose and for health care policy and research. An index created for general purposes can be used for various situations. An index created for health care policy or research purposes is developed to measure rurality specific to health care.

\section{Results}

After searching through the titles and abstracts of 1850 publications, 17 eligible publications [11, 12, 24-38] were identified. Reasons for exclusion are shown in Fig. 1.

\section{Publication characteristics of the rurality indices}

As shown in Table 1, 14 (82\%) of the 17 articles have been published since 2000. Table 2 shows that the majority $(13 ; 76 \%)$ have been published in Australia, Canada and the US. Three indices were developed in Europe (Germany, Italy, and Scotland) and only one index was developed in Asia (China). Of 17 indices, 12 (71\%) were published in a peer-reviewed journal and five were posted online on the web.

MSU Montana State University, GIS Geographic Information System, PHCWA Primary Health Care Worker Accessibility index, RRS Rural Ranking Scale, IRR Index of Relative Rurality

\section{Purposes of and factors in rurality indices}

Thirteen indices (76\%) were developed for health care policy or research purposes and four (24\%) were developed for general purpose (Table 2). The indices developed for health care policy or research were primarily designed to measure access to health care resources or to determine incentives for health care providers based on rurality. Fourteen indices (82\%) measured rurality as a continuous score.

The unit of analysis in each study was determined by the purpose of the index (Table 2). Twelve indices (71\%) employed geographical jurisdiction (such as statistical local area, county, state, or postal code) as a unit of analysis. Three focused on a medical institution (general practice) and two targeted individuals as the unit of analysis. The factors included in each rurality index are 


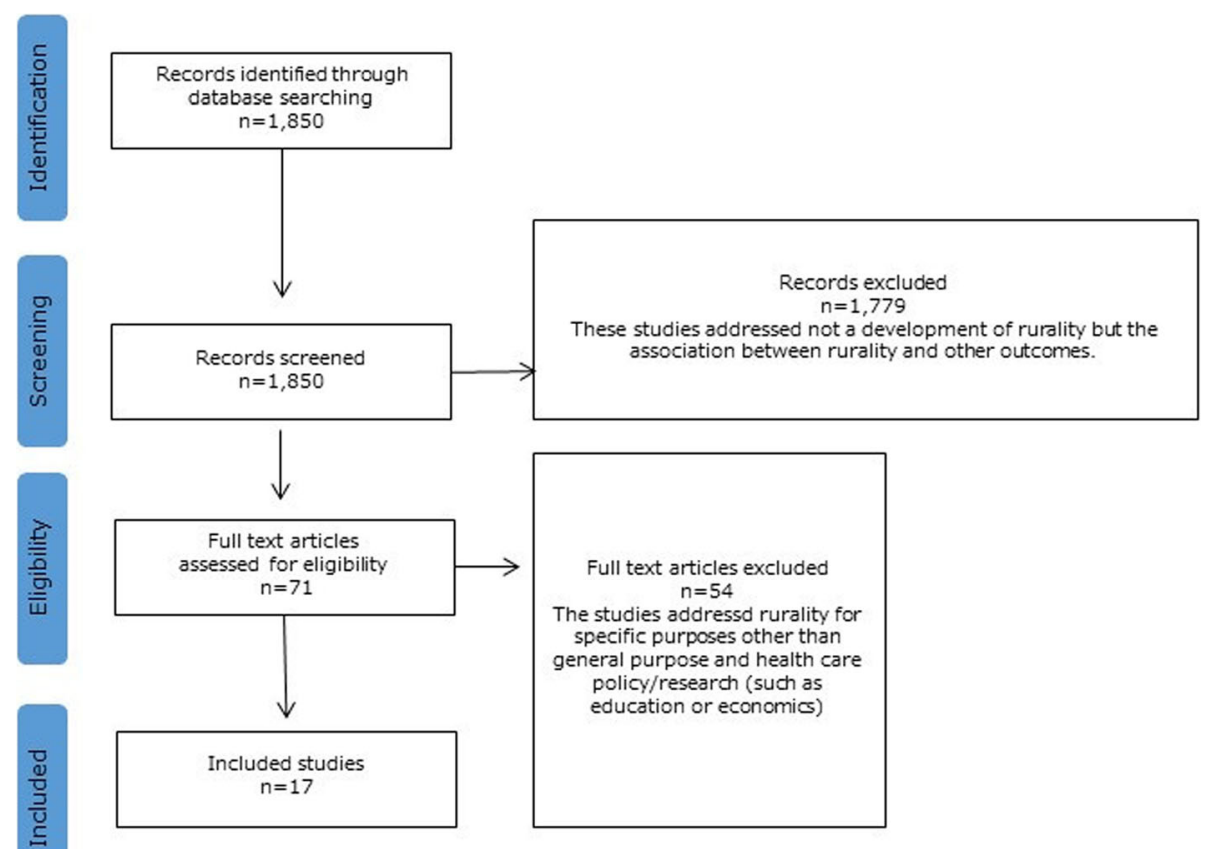

Fig. 1 Flow diagram for the selection of studies in the systematic scoping review

Table 1 Publication characteristics of the rurality indices

\begin{tabular}{|c|c|c|c|}
\hline Author and publication year & Country & $\begin{array}{l}\text { Peer review (yes/ } \\
\text { no) }\end{array}$ & $\begin{array}{l}\text { Citation index by Web of } \\
\text { Science }\end{array}$ \\
\hline $\begin{array}{l}\text { Department of Primary Industries and Energy, Department of Human Services and } \\
\text { Health, } 1994 \text { [24] }\end{array}$ & Australia & No & not included \\
\hline Weinert et al., 1995 [25] & USA & Yes & 38 \\
\hline Leduc, 1997 [26] & Canada & Yes & not included \\
\hline Department of Health and Aged Care, 2001 [27] & Australia & No & not included \\
\hline Australian Institute of Health and Welfare Canberra, 2004 [28] & Australia & No & not included \\
\hline Swan et al., 2008 [29] & Scotland & Yes & 9 \\
\hline Kralj, 2008 [11] & Canada & No & not included \\
\hline McGrail et al., 2009 [30] & Australia & Yes & 61 \\
\hline Han et al., 2012 [31] & China & Yes & 9 \\
\hline Humphreys et al., 2012 [13] & Australia & Yes & not included \\
\hline Steinhaeuser et al., 2014 [32] & Germany & Yes & 8 \\
\hline Mao et al., 2015 [33] & USA & Yes & 4 \\
\hline Zhu et al., 2015 [34] & USA & Yes & not included \\
\hline Inagami et al., 2016 [35] & USA & Yes & 3 \\
\hline Alasia et al., 2017 [36] & Canada & No & 6 \\
\hline Calovi et al., 2018 [37] & Italy & Yes & 0 \\
\hline Doogan et al., 2018 [38] & USA & Yes & 0 \\
\hline
\end{tabular}


Table 2 Description of purpose, types of factors included, and unit of analysis of rurality indices

\begin{tabular}{|c|c|c|c|c|c|}
\hline Author and publication year & $\begin{array}{l}\text { Name of the } \\
\text { index }\end{array}$ & $\begin{array}{l}\text { Purpose of the index (for } \\
\text { general purpose or health } \\
\text { care policy and research) }\end{array}$ & $\begin{array}{l}\text { Types of } \\
\text { variables: } \\
\text { continuous or } \\
\text { categorical }\end{array}$ & Unit of analysis & $\begin{array}{l}\text { How to decide the } \\
\text { included factors }\end{array}$ \\
\hline $\begin{array}{l}\text { Department of Primary Industries } \\
\text { and Energy, Department of Human } \\
\text { Services and Health, } 1994 \text { [24] }\end{array}$ & $\begin{array}{l}\text { Rural, remote and } \\
\text { metropolitan area } \\
\text { (RRMA) }\end{array}$ & for general purpose & categorical & $\begin{array}{l}\text { geographical } \\
\text { jurisdiction: } \\
\text { Statistical Local } \\
\text { Area }\end{array}$ & $\begin{array}{l}\text { consensus of a working } \\
\text { group }\end{array}$ \\
\hline Weinert et al., 1995 [25] & MSU rurality index & $\begin{array}{l}\text { for health care policy and } \\
\text { research }\end{array}$ & continuous & individual & $\begin{array}{l}\text { literature review and } \\
\text { availability of the data }\end{array}$ \\
\hline Leduc, 1997 [26] & $\begin{array}{l}\text { General Practice } \\
\text { Rurality Index (GPRI) }\end{array}$ & $\begin{array}{l}\text { for health care policy and } \\
\text { research }\end{array}$ & continuous & $\begin{array}{l}\text { health care } \\
\text { institution: general } \\
\text { practice }\end{array}$ & literature review \\
\hline $\begin{array}{l}\text { Department of Health and Aged } \\
\text { Care, } 2001 \text { [27] }\end{array}$ & $\begin{array}{l}\text { Accessibility/ } \\
\text { Remoteness Index } \\
\text { of Australia (ARIA) }\end{array}$ & for general purpose & continuous & $\begin{array}{l}\text { geographical } \\
\text { jurisdiction: } \\
\text { populated } \\
\text { location }\end{array}$ & GIS network analysis \\
\hline $\begin{array}{l}\text { Australian Institute of Health and } \\
\text { Welfare Canberra, } 2004 \text { [28] }\end{array}$ & $\begin{array}{l}\text { Australian Standard } \\
\text { Geographical } \\
\text { Classification } \\
\text { (ASGC) }\end{array}$ & for general purpose & continuous & $\begin{array}{l}\text { geographical } \\
\text { jurisdiction: } \\
\text { Statistical Local } \\
\text { Area }\end{array}$ & $\begin{array}{l}\text { An enhanced measure } \\
\text { of previous remoteness } \\
\text { index, ARIA+ }\end{array}$ \\
\hline Swan et al., 2008 [29] & $\begin{array}{l}\text { Clinical } \\
\text { peripherality } \\
\text { indicator }\end{array}$ & $\begin{array}{l}\text { for health care policy and } \\
\text { research }\end{array}$ & continuous & $\begin{array}{l}\text { health care } \\
\text { institution: general } \\
\text { practice }\end{array}$ & factor analysis \\
\hline Kralj, 2008 [11] & $\begin{array}{l}\text { Rurality Index for } \\
\text { Ontario (RIO) }\end{array}$ & $\begin{array}{l}\text { for health care policy and } \\
\text { research }\end{array}$ & continuous & $\begin{array}{l}\text { geographical } \\
\text { jurisdiction: } \\
\text { community }\end{array}$ & $\begin{array}{l}\text { principal component } \\
\text { analysis, maximum } \\
\text { likelihood method }\end{array}$ \\
\hline McGrail et al., 2009 [30] & $\begin{array}{l}\text { Index of Rural } \\
\text { Access }\end{array}$ & $\begin{array}{l}\text { for health care policy and } \\
\text { research }\end{array}$ & continuous & $\begin{array}{l}\text { geographical } \\
\text { jurisdiction: } \\
\text { collection district }\end{array}$ & $\begin{array}{l}\text { modified two-step float- } \\
\text { ing catchment area } \\
\text { method }\end{array}$ \\
\hline Han et al., 2012 [31] & Rural PHCWA index & $\begin{array}{l}\text { for health care policy and } \\
\text { research }\end{array}$ & continuous & $\begin{array}{l}\text { geographical } \\
\text { jurisdiction: } \\
\text { county }\end{array}$ & literature review \\
\hline Humphreys et al., 2012 [13] & $\begin{array}{l}\text { six-level } \\
\text { geographical } \\
\text { classification }\end{array}$ & $\begin{array}{l}\text { for health care policy and } \\
\text { research }\end{array}$ & categorical & $\begin{array}{l}\text { geographical } \\
\text { jurisdiction: city }\end{array}$ & $\begin{array}{l}\text { Geo-coded data and the } \\
\text { previous study }\end{array}$ \\
\hline Steinhaeuser et al., 2014 [32] & $\begin{array}{l}\text { modified RRS- } \\
\text { Germany (mRRS-G) }\end{array}$ & $\begin{array}{l}\text { for health care policy and } \\
\text { research }\end{array}$ & continuous & $\begin{array}{l}\text { health care } \\
\text { institution: general } \\
\text { practice }\end{array}$ & $\begin{array}{l}\text { translation and } \\
\text { adaptation of the } \\
\text { previous rurality index, } \\
\text { RRS }\end{array}$ \\
\hline Mao et al., 2015 [33] & $\begin{array}{l}\text { Individual-based } \\
\text { rurality and well- } \\
\text { being measures }\end{array}$ & $\begin{array}{l}\text { for health care policy and } \\
\text { research }\end{array}$ & continuous & individual & active space approach \\
\hline Zhu et al., 2015 [34] & Rural taxonomy & $\begin{array}{l}\text { for health care policy and } \\
\text { research }\end{array}$ & categorical & $\begin{array}{l}\text { geographical } \\
\text { jurisdiction: } \\
\text { primary care } \\
\text { service area }\end{array}$ & cluster analysis \\
\hline Inagami et al., 2016 [35] & IRR zip & $\begin{array}{l}\text { for health care policy and } \\
\text { research }\end{array}$ & continuous & $\begin{array}{l}\text { geographical } \\
\text { jurisdiction: zip- } \\
\text { code level }\end{array}$ & $\begin{array}{l}\text { modification of the } \\
\text { previous rurality index, } \\
\text { Index of Relative Rurality }\end{array}$ \\
\hline Alasia et al., 2017 [36] & $\begin{array}{l}\text { index of } \\
\text { remoteness }\end{array}$ & for general purpose & continuous & $\begin{array}{l}\text { geographical } \\
\text { jurisdiction: } \\
\text { census subdivision }\end{array}$ & gravity model \\
\hline Calovi et al., 2018 [37] & $\begin{array}{l}\text { spatial accessibility } \\
\text { index }\end{array}$ & $\begin{array}{l}\text { for health care policy and } \\
\text { research }\end{array}$ & continuous & $\begin{array}{l}\text { geographical } \\
\text { jurisdiction: } \\
\text { municipality }\end{array}$ & $\begin{array}{l}\text { two-step floating } \\
\text { catchment area method }\end{array}$ \\
\hline Doogan et al., 2018 [38] & Isolation scale & $\begin{array}{l}\text { for health care policy and } \\
\text { research }\end{array}$ & continuous & $\begin{array}{l}\text { geographical } \\
\text { jurisdiction: } \\
\text { census tract }\end{array}$ & literature review \\
\hline
\end{tabular}


Table 3 Publication details and included factors of rurality indices

\begin{tabular}{|c|c|c|c|c|c|}
\hline Author and publication year & $\begin{array}{l}\text { Name of the } \\
\text { index }\end{array}$ & Population yes/no & $\begin{array}{l}\text { Travel distance } \\
\text { yes/no }\end{array}$ & Travel time yes/no & $\begin{array}{l}\text { Travel } \\
\text { cost } \\
\text { yes/no }\end{array}$ \\
\hline $\begin{array}{l}\text { Department of Primary Industries and } \\
\text { Energy, Department of Human } \\
\text { Services and Health, } 1994 \text { [24] }\end{array}$ & $\begin{array}{l}\text { Rural, remote } \\
\text { and } \\
\text { metropolitan } \\
\text { area (RRMA) }\end{array}$ & yes (population size) & no & no & no \\
\hline Weinert et al., 1995 [25] & $\begin{array}{l}\text { MSU rurality } \\
\text { index }\end{array}$ & yes (population size) & $\begin{array}{l}\text { yes (distance to } \\
\text { emergency care) }\end{array}$ & no & no \\
\hline Leduc, 1997 [26] & $\begin{array}{l}\text { General } \\
\text { Practice } \\
\text { Rurality Index } \\
\text { (GPRI) }\end{array}$ & yes (population size) & $\begin{array}{l}\text { yes (distance to } \\
\text { basic/advanced } \\
\text { referral center) }\end{array}$ & no & no \\
\hline $\begin{array}{l}\text { Department of Health and Aged } \\
\text { Care, } 2001 \text { [27] }\end{array}$ & $\begin{array}{l}\text { Accessibility/ } \\
\text { Remoteness } \\
\text { Index of } \\
\text { Australia } \\
\text { (ARIA) }\end{array}$ & no & $\begin{array}{l}\text { yes (distance to } \\
\text { the nearest } \\
\text { centre) }\end{array}$ & no & no \\
\hline $\begin{array}{l}\text { Australian Institute of Health and } \\
\text { Welfare Canberra, } 2004 \text { [28] }\end{array}$ & $\begin{array}{l}\text { Australian } \\
\text { Standard } \\
\text { Geographical } \\
\text { Classification } \\
\text { (ASGC) }\end{array}$ & no & $\begin{array}{l}\text { yes (distance to } \\
\text { the nearest } \\
\text { centre/the service } \\
\text { town) }\end{array}$ & no & no \\
\hline Swan et al., 2008 [29] & $\begin{array}{l}\text { Clinical } \\
\text { peripherality } \\
\text { indicator }\end{array}$ & yes (population density) & no & $\begin{array}{l}\text { yes (travel time to nearest specialist } \\
\text { led hospital and to Health Board } \\
\text { administrative headquarters) }\end{array}$ & no \\
\hline Kralj, 2008 [11] & $\begin{array}{l}\text { Rurality Index } \\
\text { for Ontario } \\
\text { (RIO) }\end{array}$ & $\begin{array}{l}\text { yes (population size and } \\
\text { population density) }\end{array}$ & no & $\begin{array}{l}\text { yes (travel time to nearest basic } \\
\text { referral centre and to nearest } \\
\text { advanced referral centre) }\end{array}$ & no \\
\hline McGrail et al., 2009 [30] & $\begin{array}{l}\text { Index of Rural } \\
\text { Access }\end{array}$ & yes: (population size) & no & no & no \\
\hline Han et al., 2012 [31] & $\begin{array}{l}\text { Rural PHCWA } \\
\text { index }\end{array}$ & yes (population density) & no & no & no \\
\hline Humphreys et al., 2012 [13] & $\begin{array}{l}\text { six-level } \\
\text { geographical } \\
\text { classification }\end{array}$ & yes (population size) & $\begin{array}{l}\text { yes (geographical } \\
\text { remoteness) }\end{array}$ & no & no \\
\hline Steinhaeuser et al., 2014 [32] & $\begin{array}{l}\text { modified RRS- } \\
\text { Germany } \\
\text { (mRRS-G) }\end{array}$ & no & no & $\begin{array}{l}\text { yes (travel time from the practice to } \\
\text { next major hospital, to the nearest } \\
\text { general practitioner colleague at } \\
\text { place of work, to the satellite clinic } \\
\text { and to most distant boundary } \\
\text { covered by the practice) }\end{array}$ & no \\
\hline Mao et al., 2015 [33] & $\begin{array}{l}\text { Individual- } \\
\text { based rurality } \\
\text { and well- } \\
\text { being } \\
\text { measures }\end{array}$ & yes (population density) & no & no & no \\
\hline Zhu et al., 2015 [34] & $\begin{array}{l}\text { Rural } \\
\text { taxonomy }\end{array}$ & no & no & no & no \\
\hline Inagami et al., 2016 [35] & IRR zip & $\begin{array}{l}\text { yes (population size and } \\
\text { density) }\end{array}$ & $\begin{array}{l}\text { yes (distance to } \\
\text { metropolitan } \\
\text { statistical area/ } \\
\text { micropolitan } \\
\text { statistical area) }\end{array}$ & no & no \\
\hline Alasia et al., 2017 [36] & $\begin{array}{l}\text { index of } \\
\text { remoteness }\end{array}$ & yes (population size) & no & yes (travel time) & yes \\
\hline Calovi et al., 2018 [37] & $\begin{array}{l}\text { spatial } \\
\text { accessibility } \\
\text { index }\end{array}$ & no & $\begin{array}{l}\text { yes (distance to } \\
\text { outpatient clinics) }\end{array}$ & no & no \\
\hline Doogan et al., 2018 [38] & Isolation scale & no & yes & yes & no \\
\hline
\end{tabular}


Table 3 Publication details and included factors of rurality indices (Continued)

\begin{tabular}{lllll}
\hline Author and publication year & $\begin{array}{l}\text { Name of the } \\
\text { index }\end{array}$ & $\begin{array}{l}\text { Population yes/no } \\
\text { yes/no }\end{array}$ & $\begin{array}{l}\text { Travel distance } \\
\text { yes }\end{array}$ & $\begin{array}{l}\text { Travel time yes/no } \\
\text { cost } \\
\text { yes/no }\end{array}$ \\
\hline
\end{tabular}

\begin{tabular}{llll}
\hline Health care resources yes/no & $\begin{array}{l}\text { Health care } \\
\text { needs yes/no }\end{array}$ & Others & Formula \\
no & no & $\begin{array}{l}\text { level in urban hierarchy not applicable } \\
\text { (small/large/metropolitan/ } \\
\text { capital city urban center) }\end{array}$ &
\end{tabular}

Four mathematical operations are performed as below: 1. Distance and population measures are transformed to make the distribution of the resulting index as normal as possible 2. The transformed distance and population measures are standardized so that each has a standard deviation of one 3. The standardized transformed distance and population measures are weighted to produce an initial index of rurality that assigns high scores to rural families and low scores to urban families

4. The initial index constructed in operation \#3 is restandardized to have a mean of zero and a standard deviation of one

yes (number of general practitioners, number of specialists, presence of an acute care hospital)

yes (the number of full-time equivalent services at location and the population-to-provider ratio)

yes (primary health care worker density per 1000 farming population index)

no

yes (backup by a paramedic team within 15 min and numbers of GP which engaged in on-call duty)

yes (density of health facilities/social service facilities)

no list) no

yes (number of patients on the practice

yes (health needs (Disability Adjusted Life Years: DALYs))

mobility (households without a car, individuals of low personal mobility and public transport availability)

Sum the points for each of the following (maximum 100 points):

1. Remoteness from closest advanced referral centre $(\mathrm{km}) \div 50$

2. Remoteness from closest basic referral centre $(\mathrm{km}) \div 25$

3. $20^{*}$ (Drawing population $\div 2000$ )

4. $(20 \div$ number of full-time GPs with main place of business

within $25 \mathrm{~km}$ of the centre of the community

5. Number of specialists

6. Presence of an acute care hospital

unweighted addition of the four (threshold-limited) ratio values for each of the four levels of service centre

calculates distance to the nearest centre in each of five categories of service centre

Practice list size, ward population density and travel time to hospital were log transformed to achieve near normality. The relationships among the variables were assessed by matrix plots and correlation coefficients. This was further multiplied by 100 for the index to range from 0 to 100 with a midpoint of 50 . Higher values represent greater peripherality.

Sum the points for each of the following (maximum 100 points): 1. Measure of community population and population density

2. Measure of travel time to nearest basic referral centre

3. Measure of travel time to nearest advanced referral centre

$\sum_{j}^{\{100,10 \mathrm{~min}\}} f 2(d i j)^{*} \mathrm{R} j^{*}$ Mobi

$f(d i j)$ : impedance function

Rj: the population-to-provider ratio for service $j$

Mobi: equal to one within the initial catchment (10 min), and is less than one in the secondary catchment for areas of low mobility

Rural PHCWA index of $X$ province $=$ primary health care worker density per 1000 farming population index of $X$ province * population density index of $X$ province.

not applicable

Sum the following six variables:

1. travelling time from the surgery to major hospital

2. on-call duty

3. receiving timely backup by a paramedic team

4. travelling time to nearest general practitioner colleague at place of work

5. travelling time to most distant practice boundary

6. satellite clinic

number of different ethnic groups/degree of land development/mean
$\sum_{L=1}^{n}$ Probl, $^{*}$ RuralDegree $_{L} \sum_{L=1}^{n}$ ProbL,$i$

1. $\mathrm{n}$ is the total number of places within individual i's activity 
Table 3 Publication details and included factors of rurality indices (Continued)

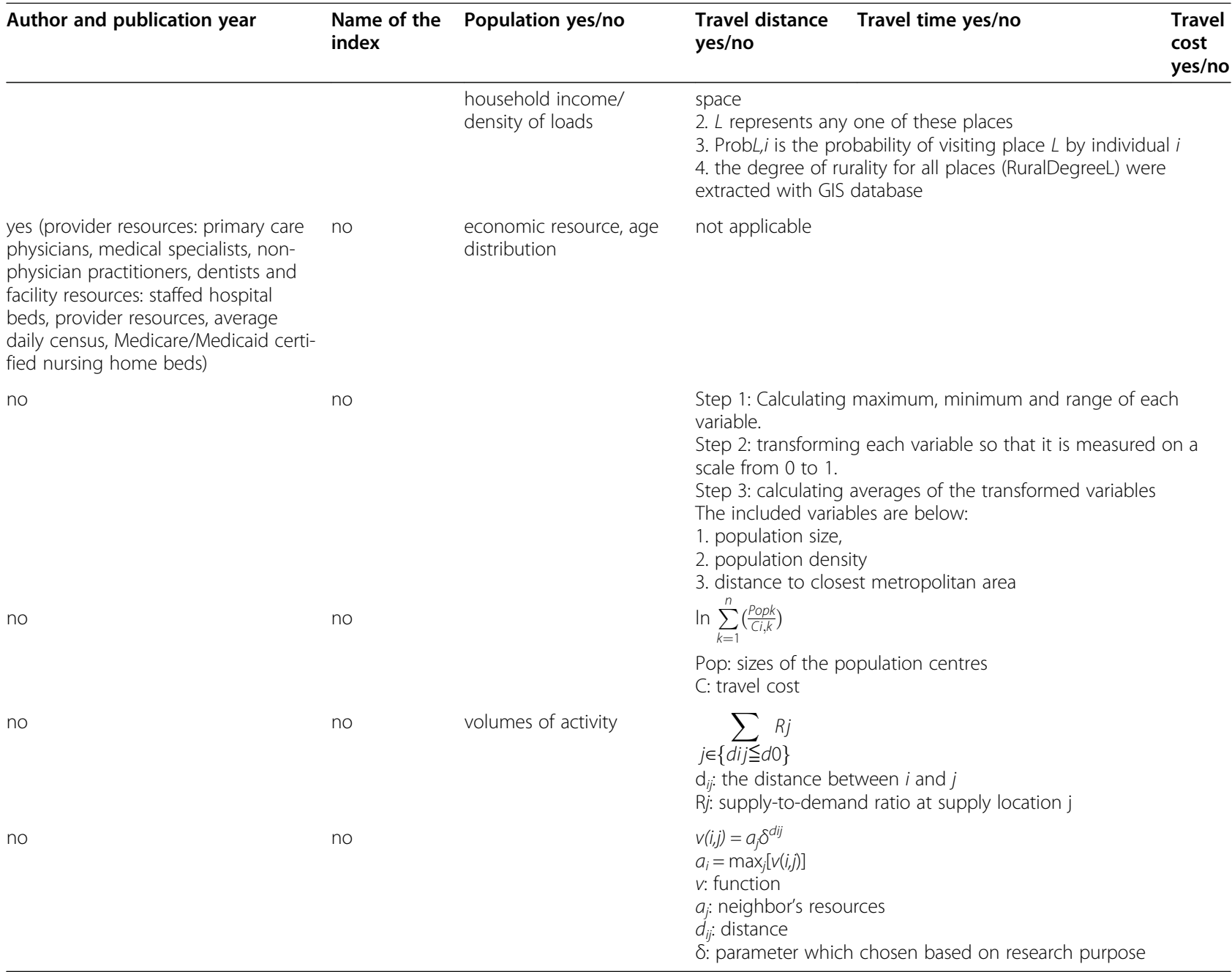

shown in Table 3. These factors were included in an index based on previous literature search and the availability of data related to the factor. The most frequently used factor was population (size or density) $(n=11$ : $65 \%)$. Travel distance and time to emergency care and/ or referral centre were also often employed ( $n=7: 41 \%$ and 3: $18 \%$, respectively). In four indices (24\%), resource availability expressed either as the number of physicians (both primary care and specialists) or as physician/population ratio was included in the index.

MSU Montana State University, GIS Geographic Information System, PHCWA Primary Health Care Worker Accessibility index, $R R S$ Rural Ranking Scale, IRR Index of Relative Rurality

The 14 indices (82\%) that calculated a continuous rurality score used a mathematical formula: e.g. summing up the included variables, log transformation or a more complex operation (Table 4). The formulas measured rurality as a continuous variable, such as 0 to 1 or 0 to 100. Geographic Information System (GIS) was used in five studies (29\%), of which two studies (12\%) employed a two-step floating catchment area method to assess geographical accessibility.

MSU Montana State University, GIS Geographic Information System, PHCWA Primary Health Care Worker Accessibility index, $R R S$ Rural Ranking Scale, IRR Index of Relative Rurality

\section{Validity and reliability properties}

Fifteen indices $(88 \%)$ did not examine reliability and 12 indices (71\%) did not examine validity (Table 4). In some studies, test/re-test and Cronbach's alpha were used to assess reliability. Validity was confirmed by examining correlation of the index with other measures.

\section{Discussion}

The scoping systematic review found 17 rurality indices from seven countries. We found that these indices were designed specifically for health care research and policy purposes than general use. This review found that while 
Table 4 Validity and reliability properties of rurality measures

\begin{tabular}{|c|c|c|c|c|c|}
\hline Author and publication year & Name of the index & $\begin{array}{l}\text { Reliability } \\
\text { measures }\end{array}$ & $\begin{array}{l}\text { Reliability } \\
\text { score }\end{array}$ & Validity measures & Validity score \\
\hline $\begin{array}{l}\text { Department of Primary Industries and } \\
\text { Energy, Department of Human } \\
\text { Services and Health, } 1994 \text { [24] }\end{array}$ & $\begin{array}{l}\text { Rural, remote and } \\
\text { metropolitan area } \\
\text { (RRMA) }\end{array}$ & $\begin{array}{l}\text { not } \\
\text { applicable }\end{array}$ & $\begin{array}{l}\text { not } \\
\text { applicable }\end{array}$ & not applicable & not applicable \\
\hline Weinert et al., 1995 [25] & MSU rurality index & test/re-test & $\begin{array}{l}0.94 \text { or } \\
\text { larger }\end{array}$ & $\begin{array}{l}\text { concurrent validity (comparison with } \\
\text { other measure such as the participants' } \\
\text { perception) }\end{array}$ & $\begin{array}{l}R^{2}=0.41, r=0.85 \\
\text { and } Z=4.09\end{array}$ \\
\hline Leduc, 1997 [26] & $\begin{array}{l}\text { General Practice } \\
\text { Rurality Index (GPRI) }\end{array}$ & $\begin{array}{l}\text { not } \\
\text { applicable }\end{array}$ & $\begin{array}{l}\text { not } \\
\text { applicable }\end{array}$ & not applicable & not applicable \\
\hline $\begin{array}{l}\text { Department of Health and Aged } \\
\text { Care, } 2001 \text { [27] }\end{array}$ & $\begin{array}{l}\text { Accessibility/ } \\
\text { Remoteness Index } \\
\text { of Australia (ARIA) }\end{array}$ & $\begin{array}{l}\text { not } \\
\text { applicable }\end{array}$ & $\begin{array}{l}\text { not } \\
\text { applicable }\end{array}$ & not applicable & not applicable \\
\hline $\begin{array}{l}\text { Australian Institute of Health and } \\
\text { Welfare Canberra, } 2004 \text { [28] }\end{array}$ & $\begin{array}{l}\text { Australian Standard } \\
\text { Geographical } \\
\text { Classification (ASGC) }\end{array}$ & $\begin{array}{l}\text { not } \\
\text { applicable }\end{array}$ & $\begin{array}{l}\text { not } \\
\text { applicable }\end{array}$ & not applicable & not applicable \\
\hline Swan et al., 2008 [29] & $\begin{array}{l}\text { Clinical peripherality } \\
\text { indicator }\end{array}$ & $\begin{array}{l}\text { not } \\
\text { applicable }\end{array}$ & $\begin{array}{l}\text { not } \\
\text { applicable }\end{array}$ & not applicable & not applicable \\
\hline Kralj, 2008 [11] & $\begin{array}{l}\text { The Rurality Index } \\
\text { for Ontario (RIO) }\end{array}$ & $\begin{array}{l}\text { not } \\
\text { applicable }\end{array}$ & $\begin{array}{l}\text { not } \\
\text { applicable }\end{array}$ & not applicable & not applicable \\
\hline McGrail et al., 2009 [30] & $\begin{array}{l}\text { the Index of Rural } \\
\text { Access }\end{array}$ & $\begin{array}{l}\text { not } \\
\text { applicable }\end{array}$ & $\begin{array}{l}\text { not } \\
\text { applicable }\end{array}$ & not applicable & not applicable \\
\hline Han et al., 2012 [31] & Rural PHCWA index & $\begin{array}{l}\text { not } \\
\text { applicable }\end{array}$ & $\begin{array}{l}\text { not } \\
\text { applicable }\end{array}$ & not applicable & not applicable \\
\hline Humphreys et al., 2012 [13] & $\begin{array}{l}\text { six-level } \\
\text { geographical } \\
\text { classification }\end{array}$ & $\begin{array}{l}\text { not } \\
\text { applicable }\end{array}$ & $\begin{array}{l}\text { not } \\
\text { applicable }\end{array}$ & concurrent validity & \\
\hline Steinhaeuser et al., 2014 [32] & $\begin{array}{l}\text { modified RRS- } \\
\text { Germany (mRRS-G) }\end{array}$ & $\begin{array}{l}\text { Cronbach's } \\
\text { alpha }\end{array}$ & negative & convergent construct validity & $\begin{array}{l}\text { factor analysis: } R^{2}= \\
59.4 \%\end{array}$ \\
\hline Mao et al., 2015 [33] & $\begin{array}{l}\text { Individual-based } \\
\text { rurality and well- } \\
\text { being measures }\end{array}$ & $\begin{array}{l}\text { not } \\
\text { applicable }\end{array}$ & $\begin{array}{l}\text { not } \\
\text { applicable }\end{array}$ & not applicable & not applicabl \\
\hline Zhu et al., 2015 [34] & Rural taxonomy & $\begin{array}{l}\text { not } \\
\text { applicable }\end{array}$ & $\begin{array}{l}\text { not } \\
\text { applicable }\end{array}$ & not applicable & not applicable \\
\hline Inagami et al., 2016 [35] & IRR zip & $\begin{array}{l}\text { not } \\
\text { applicable }\end{array}$ & $\begin{array}{l}\text { not } \\
\text { applicable }\end{array}$ & face validity & not applicable \\
\hline Alasia et al., 2017 [36] & $\begin{array}{l}\text { the index of } \\
\text { remoteness }\end{array}$ & $\begin{array}{l}\text { not } \\
\text { applicable }\end{array}$ & $\begin{array}{l}\text { not } \\
\text { applicable }\end{array}$ & not applicable & not applicable \\
\hline Calovi et al., 2018 [37] & $\begin{array}{l}\text { The spatial } \\
\text { accessibility index }\end{array}$ & $\begin{array}{l}\text { not } \\
\text { applicable }\end{array}$ & $\begin{array}{l}\text { not } \\
\text { applicable }\end{array}$ & not applicable & not applicable \\
\hline Doogan et al., 2018 [38] & Isolation scale & $\begin{array}{l}\text { not } \\
\text { applicable }\end{array}$ & $\begin{array}{l}\text { not } \\
\text { applicable }\end{array}$ & $\begin{array}{l}\text { Spearman correlation to test } \\
\text { convergent validity and the Akaike } \\
\text { information criterion for criterion } \\
\text { validity }\end{array}$ & $\begin{array}{l}\text { Spearman } \\
\text { correlation for } \\
\text { convergent validity } \\
r=0.99\end{array}$ \\
\hline
\end{tabular}

the concept of rurality and concerns about barriers to access to care for rural residents is shared by many countries the approach to constructing an index was highly context specific. Although many indices were included, population size/density and travel time/distance to an advanced medical centre, none of the factors were used in all indices. These findings are consistent with earlier literature reviews that also found that a rurality index is generally based on population size or density and measures of distance such as travel time [39].
Although social, cultural, economic factors are associated with rurality $[14,15]$, none of the indices incorporated these factors. These factors may be relevant in the development of a rurality index for Japan. For example, the clinical peripherality index in Scotland accounted for local characteristics such as location on an island [29]. Similarly, Japan has many remote islands [16] and sometimes a patient can access a secondary hospital only by a ship or an airplane. The rurality index in Japan has to consider frequency/number of a round-trip flights or 
water transport. Additional travel related factors such as the quality of roads, availability of public transport, difficulty of the terrain, and weather (e.g. amount of annual snowfall) may be important considerations in the Japanese context.

In terms of reliability and validity, only 12 and $29 \%$ of all indices examined these measures, respectively. Reliability refers to the consistent interpretation and application. In terms of validity, content validity, such as face validity, may be more important than other forms of validity due to the highly contextual nature of the index [40]. Thus, gathering advice from health care providers and policy makers may be an important step in developing a rurality index for Japan.

\section{Study strengths}

To the best of our knowledge, this is the first systematic scoping review about the methods and measures used in the development of a rurality index. Given the variability in the definition of rural and uses of a rurality index, a systematic review may never be an appropriate review method. However, summarizing information from existing indices through a scoping review s helpful in the development of new rurality index.

\section{Study limitations}

This study has several limitations. First, we may have excluded potential indices, such as, an index developed for a specific research question or analysis that may not be generalizable or useful in developing a standardized rurality index. We also excluded classification schemes based on population or census area because these classifications do not take access to health care resources into account.

\section{Conclusion}

We identified 17 rurality indices by conducting the systematic scoping review. Although the operationalization of rurality is highly context specific, some variables were frequently employed in multiple countries/areas. The results will be helpful to develop a rurality index in Japan and other countries/areas.

\section{Abbreviations \\ GALLOP: Government and Legislative Libraries Online Publications Portal; MMM: Modified Monash Model; OECD: Organization for Economic Co- operation and Development; RIO: Rurality Index of Ontario}

\section{Acknowledgements}

We thank David Le Sauvage, a retired member of Western Libraries Teaching and Learning Team and the Canadian Library of Family Medicine, for his assistance in the developing the search strategy, and Machiko Inoue, Department of Family and Community Medicine, Hamamatsu University School of Medicine, for the warm support in the planning the study. We also thank the members of the committee of rural and remote medicine in the Japan Primary Care Association.

\section{Authors' contributions}

MK designed the study. MK and RO participated in the implementation, data collection and data analysis. MK took part in writing of the manuscript. MK also serves as the guarantor. EV, MM and TF contributed the design of the study and critically reviewed the manuscript. All authors had full access to the data and take responsibility for the integrity of the data and accuracy of the analysis. The author(s) read and approved the final manuscript.

\section{Funding}

This study was supported by the Grant-in-Aid for Young Scientists. The study sponsor had no role in the study design, data collection, analysis and interpretation, writing of the report, or the decision to submit the article for publication.

\section{Availability of data and materials}

All data relevant to the study are included in the article.

\section{Ethics approval and consent to participate}

The study did not require ethical approval because the study was a review of the published articles and websites.

\section{Consent for publication}

Not applicable.

\section{Competing interests}

There are no potential competing interests to be declared relevant to this work.

\section{Author details}

${ }^{1}$ Primary Care Research Unit, Graduate School of Health Data Science, Yokohama City University, 22-2, Seto, Kanazawa-ku, Yokohama, Kanagawa 236-0027, Japan. ${ }^{2}$ Department of Family and Community Medicine, Hamamatsu University School of Medicine, 1-20-1, Handayama, Higashi-ku, Hamamatsu 431-3192, Japan. ${ }^{3}$ Department of Family Medicine, Schulich School of Medicine \& Dentistry, Western Centre for Public Health and Family Medicine, London, Ontario, Canada. ${ }^{4}$ Department of Community Care, Unnan City Hospital, 699-1221 96-1 lida, Daito-Cho, Unnan City, Shimane, Japan.

Received: 11 June 2020 Accepted: 8 December 2020

Published online: 04 January 2021

\section{References}

1. Patterson PD, Moore CG, Probst JC, Shinogle JA. Obesity and physical inactivity in rural America. J Rural Health. 2004;20(2):151-9.

2. Krishna S, Gillespie KN, Mcbride TM. Diabetes burden and access to preventive care in the rural United States. J Rural Health. 2010;26(1):3-11.

3. Parks SE, Housemann RA, Brownson RC. Differential correlates of physical activity in urban and rural adults of various socioeconomic backgrounds in the United States. J Epidemiol Community Health. 2003;57(1):29-35.

4. Michimi A, Wimberly MC. Associations of supermarket accessibility with obesity and fruit and vegetable consumption in the conterminous United States. Int J Health Geogr. 2010;9:49.

5. Casey MM, Thiede call K, Klingner JM. Are rural residents less likely to obtain recommended preventive healthcare services? Am J Prev Med. 2001;21(3): $182-8$.

6. Zhang P, Tao G, Irwin KL. Utilization of preventive medical services in the United States: a comparison between rural and urban populations. J Rural Health. 2000;16(4):349-56.

7. Yen $\mathrm{H}$, Michael $Y L$, Perdue L. Neighborhood environment in studies of health of older adults: a systematic review. Am J Prev Med. 2009;37(5):45563.

8. Weaver KE, Geiger AM, Lu L, Case LD. Rural-urban disparities in health status among US cancer survivors. Cancer. 2013;19:1050-7.

9. Wallace $A E$, Lee $R$, Mackenzie TA, West AN, et al. A longitudinal analysis of rural and urban veterans' health-related quality of life. J Rural Health. 2010; 26:156-63.

10. Wilson NW, Couper ID, De Vries E, Reid S, Fish T, Marais BJ. A critical review of interventions to redress the inequitable distribution of healthcare professionals to rural and remote areas. Rural Remote Health. 2009;9(2):1060. 
11. Kralj B. Measuring Rurality - RIO2008 BASIC: methodology and results. 2008. https://www.oma.org/wp-content/uploads/2008rio-fulltechnicalpaper.pdf. Accessed 29 Apr 2020.

12. Modified Monash Model Discussion Paper, Rural Classification Technical Working Group. 2014. https://pdfs.semanticscholar.org/e2f9/c4ade1f31 fcf0dade9f0dab1758f7345a2c9.pdf. Accessed 29 Apr 2020.

13. Humphreys JS, McGrail MR, Joyce CM, Scott A, Kalb G. Who should receive recruitment and retention incentives? Improved targeting of rural doctors using medical workforce data. Aust J Rural Health. 2012;20(1):3-10.

14. Rural General Practice in the United Kingdom Cox, 1995 https://www.ncbi. nlm.nih.gov/pmc/articles/PMC2560268/. Accessed 29 Apr 2020.

15. Vanderboom CP, Madigan EA. Federal definitions of rurality and the impact on nursing research. Res Nurs Health. 2007;30(2):175-84.

16. Tokyo University Rural Health Policy Action Community, Vision of Rural health. 2014. http://www.pp.u-tokyo.ac.jp/HPU/seminar/2014-10-12/d/ Guideline_F19_rev.pdf. Accessed 29 Apr 2020. (in Japanese).

17. Ministry of Internal Affairs and Communications. Requirements for depopulated area. 2019. https://www.soumu.go.jp/main_content/00063181 8.pdf. Accessed 29 Apr 2020. (in Japanese).

18. lida S, Sakamoto A. Regional differences in Doctors' perceptions of sociopolitical countermeasures against inadequate rural medicine: content analysis of free comments from clinic-based doctors obtained from a questionnaire survey. Jichi Med Univ J. 2010;33:55-61 (in Japanese).

19. Smith T, Sutton K, Pit S, et al. Health professional students' rural placement satisfaction and rural practice intentions: a national cross-sectional survey. Aust J Rural Health. 2018;26(1):26-32.

20. Levac D, Colquhoun H, O'Brien KK. Scoping studies: advancing the methodology. Implement Sci. 2010;5(1):69.

21. Arksey H, O'Malley L. Scoping studies: towards a methodological framework. Int J Soc Res Methodol. 2005;8(1):19-32.

22. Ichushi Web: About Ichushi Web. www.jamas.or.jp/service/ichu/about.html. Accessed 29 Apr 2020. (in Japanese).

23. Tricco AC, et al. PRISMA extension for scoping reviews (PRISMA-SCR): checklist and explanation. Ann Intern Med. 2018;169(7):467-73.

24. Department of Primary Industries and Energy, Department of Human Services and Health. Rural, remote and metropolitan area. 1994. https:// www.pc.gov.au/inquiries/completed/nursing-home-subsidies/submissions/ subdr096/subdr096.pdf. Accessed 29 Apr 2020.

25. Weinert C, Boik RJ. MSU Rurality index: development and evaluation. Res Nurs Health. 1995;18(5):453-64 Montana State University.

26. Leduc E. Defining rurality: a general practice Rurality index for Canada. Can J Rural Med. 1997;2(2):125.

27. Department of Health and Aged Care. Accessibility/Remoteness Index of Australia. 2001. https://www.health.gov.au/internet/main/publishing.nsf/ Content/E2EE19FE831F26BFCA257BF0001F3DFA/\$File/ocpanew14.pdf. Accessed 29 Apr 2020

28. Australian Institute of Health and Welfare Canberra. Australian Standard Geographical Classification. 2004. https://www.aihw.gov.au/reports/ruralremote-australians/guide-to-remoteness-classifications/contents/table-ofcontents. Accessed 29 Apr 2020.

29. Swan GM, Selvaraj S, Godden DJ. Clinical peripherality: development of a peripherality index for rural health services. BMC Health Serv Res. 2008;8:23.

30. McGrail MR, Humphreys JS. The index of rural access: an innovative integrated approach for measuring primary care access. BMC Health Serv Res. 2009;9:124.

31. Han Y, Wei J, Song X, Sarah BJ, Wen C, Zheng X. Accessibility of primary health care workforce in rural China. Asia Pac J Public Health. 2012;24(5): 833-47.

32. Steinhaeuser J, Otto P, Goetz K, Szecsenyi J, Joos S. Rural area in a European country from a health care point of view: an adoption of the rural ranking scale. BMC Health Serv Res. 2014;14:147.

33. Mao L, Stacciarini JM, Smith R, Wiens B. An individual-based rurality measure and its health application: a case study of Latino immigrants in North Florida, USA. Soc Sci Med. 2015;147:300-8.

34. Zhu X, Mueller KJ, Vaughn T, Ullrich F, Rural Policy Research Institute Center for Rural Health Policy Analysis, University of lowa College of Public Health, Department of Health Management and Policy; Stratis Health. A Rural Taxonomy of Population and Health-Resource Characteristics. Rural Policy Brief. 2015:4(2015):1-6.

35. Inagami S, Gao S, Karimi H, Shendge MM, Probst JC, Stone RA. Adapting the index of relative Rurality (IRR) to estimate Rurality at the ZIP code level: a rural classification system in health services research. J Rural Health. 2016; 32(2):219-27.

36. Alasia A, Bedard F, Belanger J, Guimound F and Penny C. Measuring remoteness and accessibility-a set of indices for Canadian communities. 2017. https://www150.statcan.gc.ca/n1/pub/18-001-x/18-001-x2017002-eng. htm. Accessed 29 Apr 2020.

37. Calovi M, Seghieri C. Using a GIS to support the spatial reorganization of outpatient care services delivery in Italy. BMC Health Serv Res. 2018;18(1): 883.

38. Doogan NJ, Roberts ME, Wewers ME, Tanenbaum ER, Mumford EA, Stillman FA. Validation of a new continuous geographic isolation scale: a tool for rural health disparities research. Soc Sci Med. 2018;215:123-32.

39. Minore B, Hill ME, Pugliese I and Gauld T. Rurality literature review. 2008. https://collections.ola.org/mon/24003/299628.pdf. Accessed 29 Apr 2020.

40. Cohen SA, Kelley L, Bell AE. spatiotemporal Discordance in Five common Measures of rurality for Us counties and applications for health Disparities research in Older adults. Front Public Health. 2015;3:267.

\section{Publisher's Note}

Springer Nature remains neutral with regard to jurisdictional claims in published maps and institutional affiliations.

\section{Ready to submit your research? Choose BMC and benefit from:}

- fast, convenient online submission

- thorough peer review by experienced researchers in your field

- rapid publication on acceptance

- support for research data, including large and complex data types

- gold Open Access which fosters wider collaboration and increased citations

- maximum visibility for your research: over $100 \mathrm{M}$ website views per year

At BMC, research is always in progress.

Learn more biomedcentral.com/submissions 